\title{
PENGARUH MODEL PEMBELAJARAN DAN BERPIKIR KRITIS TERHADAP HASIL BELAJAR ILMU PENGETAHUAN ALAM SEKOLAH DASAR KOTA DEPOK
}

\author{
Nurul Fazriyah \\ Mahasiswa Pendidikan Dasar, Universitas Negeri Jakarta \\ nurulfazriyah@gmail.com
}

\begin{abstract}
This study aims to determine the effect of integrated learning model and ability to think critically about the science learning outcomes. The study was conducted in SDN Kemiri Muka 1 Depok in class V in the academic year 2014/2015 using cluster random sampling was done to 80 students. Retrieval of data obtained through the test and analyzed using Analysis of Variance (ANOVA) two-lane design with treatment by level $2 \times 2$. The results showed that: (1) Natural Sciences learning outcomes of students who are given integrated learning model thematic integrative models higher than in groups of students who are given learning model fragmented, (2) there is an interaction effect between the ability to think critically about the science subjects by learning model thematic integrative learning outcomes Natural Sciences, (3) for students who have the ability to think critically high, the result of learning science students given thematic integrative teaching model is higher than the fragmented learning model and (4) for students who have the ability to think critically low yield higher learning science using fragmented models. The conclusion showed that the thematic integrative learning model with critical thinking skills can improve student science learning outcomes .
\end{abstract}

Keywords: Model Of Integrated Learning, Critical Thinking Skills, Science Learning Outcomes

\begin{abstract}
Abstrak: Penelitian ini bertujuan untuk mengetahui pengaruh model pembelajaran terpadu dan kemampuan berpikir kritis terhadap hasil belajar IPA. Penelitian dilakukan di SDN Kemiri Muka 1 Depok pada kelas V tahun pelajaran 2014/2015 menggunakan cluster random sampling yang dilakukan kepada 80 siswa. Pengambilan data diperoleh melalui tes dan dianalisis menggunakan Analisis Varians (ANAVA) dua jalur dengan desain treatment by level $2 \times 2$. Hasil penelitian menunjukkan bahwa: (1) hasil belajar IPA siswa yang diberikan model pembelajaran terpadu model tematik integratif lebih tinggi dari pada kelompok siswa yang diberikan model pembelajaran fragmented, (2) terdapat pengaruh interaksi antara kemampuan berpikir kritis terhadap mata pelajaran IPA dengan model pembelajaran tematik integratif terhadap hasil belajar IPA, (3) bagi siswa yang memiliki kemampuan berpikir kritis tinggi, hasil belajar IPA siswa yang diberikan model pembelajaran tematik integratif lebih tinggi dari pada model pembelajaran fragmented dan (4) bagi siswa yang memiliki kemampuan berpikir kritis rendah hasil belajar IPA lebih tinggi menggunakan model fragmented. Kesimpulan menunjukkan bahwa model pembelajaran tematik integratif dengan kemampuan berpikir kritis mampu meningkatkan hasil belajar IPA siswa.
\end{abstract}

Kata kunci : Model Pembelajaran Terpadu, Kemampuan Berpikir Kritis, Hasil $\backslash$ Belajar IPA. 
Pengaruh Model Pembelajaran

Nurul Fazriyah

Pendidikan pada masa ini berorientasi menyiapkan manusia yang disebut dalam Pembukaan Undang-Undang Dasar 1945 sebagai manusia seutuhnya, yaitu manusia yang cerdas, berkompeten, dapat bersaing secara global tanpa melupakan jati dirinya sebagai makhluk Tuhan. Rasyidin (2007: 29) mengatakan bahwa agar mampu menyesuaikan diri dengan tuntutan perkembangan ilmu pengetahuan dan teknologi abad ini, maka hal yang mendesak untuk dilakukan sekarang adalah menata kembali sistem pendidikan dan pembelajaran.

Pembelajaran yang baik hendaknya mampu menjelaskan bagaimana seharusnya peserta didik belajar dan berpikir. Pembelajaran tidak hanya menghafal fakta dan konsep umum materi pelajaran seperti yang terjadi pada era industry (Trilling dan Fadel, 2009:13).

Dalam keadaan ini anak diberi kesempatan untuk mengembangkan pengetahuannya secara mandiri melalui proses komunikasi yang menghubungkan pengetahuan yang akan/harus mereka temukan. Hal ini berpengaruh pada hasil belajar yang dihasilkan. Hasil belajar IPA dapat dilihat salah satunya lewat nilai USBN SDN Kemiri Muka 1 Depok tahun 2013 yang meraih rata-rata 6,5. Maka dapat diperoleh informasi bahwa belum maksimalnya hasil belajar IPA di sekolah tersebut.
Pengujian terhadap kemampuan sains salah satunya dilakukan pada studi TIMSS (Trends in Internasional Matematics and science). Studi TIMSS dilakukan untuk kelas IV dan VIII dalam bidang matematika dan IPA yang diselenggarakan setiap empat tahun. Hasil studi TIMSS dalam bidang sains pada tahun 2011 Indonesia berada pada peringkat 40 dengan yang diikuti oleh 42 negara. Berdasarkan hasil studi internasional tersebut Indonesia penguasaan pengetahuan sains yang masih sangat jauh tertinggal. Hasil pemetaan Programme for International Student Assesment (PISA) tahun 2012 yang dipublikasi Organisation for Economic CoOperation and Development (OECD) juga menunjukkan posisi Indonesia yang berada pada peringkat 64 dari 65 negara (Aulia, 2013a; Aulia, 2013b; Aulia, 2013c; Aulia, 2013d; Driana, 2013; Napitupulu, 2013).

Hasil belajar IPA dapat dipengaruhi oleh situasi belajar yang dilakukan oleh guru di kelas. Belajar IPA menurut esensinya mempunyai tujuan, pembelajaran IPA bertujuan untuk mengembangkan cara berpikir. Ini sesuai dengan pernyataan Driver (Sumaji, 2009:120) bahwa sains merupakan konstruksi pemikiran manusia. Cara berpikir dan hubungannya dengan sains adalah cara berpikir ilmiah. Jadi, mengajarkan sains berarti mengajarkan cara berpikir ilmiah. De 
Boer (Sumaji, 2009: 120), mendeskripsikan tiga alasan mengapa cara berpikir ilmiah adalah penting.

Pertama dianjurkan bahwa usaha yang mensyaratkan untuk berpikir dalam suatu disiplin, cara yang rasional dapat memiliki efek penguatan yang menyeluruh pada intelektual yang akan membawa pada peningkatan kekuatan intelektualnya. Kedua, telah dianjurkan bahwa cara berpikir ilmiah dapat ditransfer pada isi yang ilmiah dan bagaimanapun dapat membuat orang menjadi lebih efektif dalam kehidupan sehari-hari. Ketiga, dianjurkan bahwa ilmuwan pada masa yang akan datang harus mengetahui bagaimana berpikir sebagaimana layaknya seorang ilmuwan pada masa sekarang."

Pada pembelajaran IPA, terdapat keterampilan proses yang harus dikuasai anak. Menurut Samatowa (2011:93), keterampilan proses merupakan keterampilan intelektual yang digunakan ilmuwan dalam meneliti fenomena alam. Khusus untuk pembelajaran di sekolah dasar, Harlen menyarankan hanya lima jenis keterampilan proses yang harus dikuasai, meskipun hakekatnya mencakup pula jenis keterampilan proses yang lainnya, yaitu : observing (collecting data, measuring), planning (raising questioning, predicting, devising enquiries) hypothesizing (suggesting explanation) interpreting (considering evidence, evaluating), communicating (presenting report, using secondary source).

$$
\text { Gagne dalam ICELS }
$$
mengembangkan kategori hasil belajar berdasarkan karakteristik konten/isi yang harus dikuasai siswa. Bloom dan kawankawan (Eveline, 2010: 8) membagi hasil belajar menjadi beberapa domain atau aspek kemampuan dengan berbagai karakteristiknya, yaitu : (1) kognitif, perilaku yang merupakan proses berpikir atau perilaku yang termasuk hasil kerja otak, (2) afektif, perilaku yang dimunculkan seseorang sebagai pertanda kecenderungannya untuk membuat pilihan atau keputusan untuk beraksi di dalam lingkungan tertentu, (3) psikomotorik, perilaku yang dimunculkan oleh hasil kerja fungsi tubuh manusia Selanjutnya ranah kognitif dari taksonomi Bloom direvisi oleh Anderson dan Krathwohl (2001:28) menjadi dua dimensi, yaitu dimensi proses kognitif dan dimensi pengetahuan.

Jadi, dari pendapat beberapa ahli dimuka, yang dimaksud dengan hasil belajar IPA di Sekolah Dasar ialah perubahan tingkah laku yang dapat diukur dan diamati sesudah mengikuti kegiatan pembelajaran dalam bentuk pengetahuan dan keterampilan, diperoleh dari kegiatan keterampilan proses dengan indikator melakukan observasi, menafsirkan, meramalkan, menggunakan alat 
Pengaruh Model Pembelajaran

Nurul Fazriyah

dan bahan, mengelompokkan, menerapkan konsep, mengkomunikasikan.

Model pembelajaran yang dapat membantu tercapainya hasil belajar secara efektif adalah model pembelajaran tematik integratif. Model pembelajaran tematik integratif adalah suatu model pembelajaran beranjak dari model pembelajaran terpadu (integratif learning). Model tematik integratif adalah model pembelajaran dengan menghubungkan beberapa bidang studi yang dipayungi dengan tema (webbed).

Ada kecenderungan selama ini guru mengemas pengalaman belajar siswa terkotak-kotak dengan tegas antara satu bidang studi yang lainnya, pembelajaran yang memisahkan penyajian mata-mata pelajaran secara tegas hanya akan membuat kesulitan belajar bagi siswa karena pemisahan seperti itu memberikan pengalaman belajar yang bersifat artifisial.

Sesuai konsep belajar Gestalt (Syaefudin, 2009:112) yang mengutamakan pengetahuan yang dimiliki siswa dimulai dari keseluruhan baru kemudian menuju bagianbagian. Dengan kata lain di mata siswa melihat dirinya sebagai pusat lingkungan yang merupakan secara holistik yang berangkat dari sifat konkrit.

Ketidakmengertian tentang suatu topik belum bisa mewujudkan dalam bentuk kemampuan bertanya dengan baik. Oleh karena itu pengemasan pengalaman belajar akan sangat berpengaruh terhadap kebermaknaan pengalaman tersebut bagi mereka. Pentingnya kesinambungan konsep diri serta lingkungan yang layaknya diperhatikan dalam pembelajaran IPA di SD, mendorong model pembelajaran tematik integratif perlu diselenggarakan di sekolah dasar.

Salah satu faktor internal yang mempengaruhi hasil belajar adalah kemampuan berpikir kritis. Kemampuan berpikir kritis penting untuk dikembangkan. Salah satu alasannya adalah untuk mempersiapkan peserta didik untuk kehidupan kedewasaannya. Kemampuan berpikir ini dapat dipelajari serta ditingkatkan melalui proses pembelajaran IPA di sekolah. Karena pembelajaran IPA mengembangkan rasa ingin tahu (curiosity) dan sikap kritis terhadap gejala-gejala alam.

Pembelajaran IPA hendaknya mengembangkan ranah belajar ke tingkat lebih tinggi sehingga keterampilan siswa dapat berkembang. Jika pembelajaran hanya mempelajari ranah berpikir tingkat rendah (lower order thinking skill) maka kemampuan berpikir siswa hanya sampai mengingat dan mengetahui. Pembelajaran IPA di sekolah berdasarkan pengamatan peneliti, belum memaksimalkan ranah berpikir tingkat lanjut (higher order thinking Skill) berupa analisis, 
sistesis serta evaluasi. Diharapkan pembelajaran IPA memberi perhatian pada ranah berpikir ini terutama pada keterampilan berpikir kritis. Oleh sebab itu, perlu dilakukan studi kajian tentang faktor yang mempengaruhi hasil belajar siswa. Khususnya melakukan studi pengaruh model pembelajaran tematik integratif dan keterampilan berpikir kritis dengan hasil belajar IPA siswa sekolah dasar.. Berpikir kritis menurut Facione (1990: 3) critical thinking is a purposeful, self-regulatory judgment which results in interpretation, analysis, evaluation, and inference, as well as explanation of the evidential, conceptual, methodological, criteriological, or conceptual considerations upon which that judgment is based. Sesuai dengan pendapat tersebut berpikir kritis adalah suatu tujuan, penilaian diri regulasi yang menghasilkan interpretasi, analisis, evaluasi, dan kesimpulan, serta penjelasan tentang bukti, konseptual, metodologis, criteriological, atau pertimbangan konseptual di mana penilaian yang didasarkan

Penelitian ini bertujuan untuk mengetahui: 1) Perbedaan hasil belajar IPA antara siswa yang belajar dengan menggunakan model pembelajaran tematik integratif dan siswa yang belajar menggunakan model pembelajaran fragmented. 2) Pengaruh interaksi antara model pembelajaran dan kemampuan berpikir kritis siswa terhadap hasil belajar IPA. 3) Perbedaan hasil belajar IPA antara siswa yang memiliki kemampuan berpikir kritis tinggi yang belajar dengan menggunakan model pembelajaran tematik integratif dan menggunakan model pembelajaran fragmented. 4) Perbedaan hasil belajar IPA antara peserta didik yang memiliki kemampuan berpikir kritis rendah yang belajar dengan menggunakan model pembelajaran tematik integratif dan menggunakan model pembelajaran fragmented.

\section{METODE}

Penelitian ini dilaksanakan pada siswa kelas V SD di SDN Kemiri Muka 1 Kota Depok. Adapun penelitian dilaksanakan pada semester I (ganjil) tahun pelajaran 2014/2015 yang berlangsung sejak bulan SeptemberOktober 2014. Penelitian ini menggunakan metode eksperimen, dan variabel dalam penelitian ini terdiri dari; (1). Variabel bebas adalah model pembelajaran terpadu, dan (2). Variabel terikat adalah hasil belajar IPA dan variabel atributnya adalah kemampuan berpikir kritis.

Populasi dalam penelitian ini adalah seluruh siswa kelas $\mathrm{V}$ Adapun desain penelitian ini menggunakan rancangan eksperimen by level $2 x \quad x \quad 2$. Teknik 
Pengaruh Model Pembelajaran

Nurul Fazriyah

pengambilan sampel dilakukan dengan cara cluster random sampling. Instrumen yang digunakan dalam penelitian ini yaitu: (1) instrument tes hasil belajar IPA siswa berupa tes pilihan ganda, (2) instrument kemampuan berpikir kritis berupa tes uraian. Koefisien reliabilitas instrumen hasil belajar IPA sebesar 0,868 sedangkan reliabilitas kemampuan berpikir kritis siswa sebesar 0,732 .

Teknik analisis data menggunakan ANAVA dua jalur dan pengujian simple effect dengan uji Tuckey. Pengujian normalitas dilakukan menggunakan Liliefors dan uji homogenitas dengan uji Bartlett.

\section{HASIL}

Hasil analisis dan deskripsi, perbedaan hasil belajar siswa pada mata pelajaran ilmu pengetahuan alam antara siswa yang menggunakan model pembelajaran fragmented dengan siswa yang pembelajarannya menggunakan Model Pembelajaran Tematik Integratif. Adapun rangkuman hasil penelitian dapat dilihat pada table 1 di bawah ini:

Tabel 1 Rangkuman Hasil Penelitian

\begin{tabular}{ccccccc}
\hline & $\mathbf{A}_{\mathbf{1}}$ & $\mathbf{A}_{\mathbf{2}}$ & $\mathbf{A}_{\mathbf{1}} \mathbf{B}_{\mathbf{1}}$ & $\mathbf{A}_{\mathbf{1}} \mathbf{B}_{\mathbf{2}}$ & $\mathbf{A}_{\mathbf{2}} \mathbf{B}_{\mathbf{1}}$ & $\mathbf{A}_{\mathbf{2}} \mathbf{B}_{\mathbf{2}}$ \\
& & & & & & \\
\hline Mean & 74,1 & 68,6 & 84,6 & 63,7 & 63,5 & 73,8 \\
Standar Dev. & 12,47 & 8,97 & 7,34 & 5,85 & 5,37 & 9,00 \\
Median & 64,4 & 67,5 & 85,7 & 64,1 & 61,6 & 76,7 \\
Modus & 68,5 & 67,8 & 80,9 & 66,5 & 60,2 & 75,1 \\
Varians & 155,46 & 80,43 & 53,87 & 34,22 & 28,87 & 80,96 \\
\hline
\end{tabular}

a) Pengujian hipotesis penelitian ini dilakukan dengan teknik Analisis Varians dua jalur ( ANAVA $2 \times 2$ ). Adapun hasil perhitungan ANAVA 2 jalur ini secara ringkas dapat dilihat dari tabel berikut ini: 
Tabel 1. Hasil Perhitungan dengan Anava Dua Jalur

\begin{tabular}{cccccc}
\hline Sumber Varians & $\mathrm{dk}$ & $\mathrm{JK}$ & $\mathrm{RJK}$ & $\mathrm{F}_{\text {hitung }}$ & $\mathrm{F}_{\text {tabel } \alpha=0,05}$ \\
\hline Antar Kolom & 1 & 332,75 & 332,75 & $6,72 * *$ & 4,08 \\
Antar Baris & 1 & 300,57 & 300,57 & 6,07 & \\
Interaksi & 1 & 2673,84 & 2673,84 & $54,04 * *$ & 4,07 \\
Dalam Kelompok & 40 & 1979,27 & 49,48 & & \\
\hline Total Direduksi & 43 & & & \\
\hline
\end{tabular}

b) Berdasarkan hasil pengujian hipotesis pertama, diketahui bahwa penerapan model pembelajaran tematik lebih efektif meningkatkan hasil belajar siswa. hal ini sejalan dengan yang diungkapkan oleh Hasil analisa data dengan menggunakan ANAVA dua jalur pada taraf signifikansi $\alpha=0,05$, tersebut di atas, memberikan nilai $\mathrm{F}_{\text {hitung }}=6,72$ lebih besar dari pada $\mathrm{F}_{\text {tabel }}=$ 4,08. Hal ini berarti bahwa $\mathrm{H}_{0}$ ditolak. Yang berarti bahwa rata-rata hasil belajar matematika siswa yang diberi model pembelajaran tematik integratif lebih tinggi daripada rata-rata siswa yang diberi model pembelajaran fragmented. Karena rata-rata skor hasil belajar IPA siswa yang diberi model pembelajaran tematik integratif 74,14 lebih tinggi dari rata-rata skor hasil belajar IPA siswa yang menggunakan model fragmented 68,64 maka disimpulkan bahwa hasil belajar IPA siswa model pembelajaran tematik integratif lebih tinggi dari hasil belajar siswa yang menggunakan model fragmented. c) Pembuktian ini menguatkan hipotesis penelitian serta menolak H0, dapat dikuatkan dengan hasil penelitian yang relevan bahwa Ahmad (2010:150) dalam penelitiannya mengemukakan bahwa pembelajaran terpadu dengan pendekatan konstruktivistik dan kooperatif terbukti dapat meningkatkan kemampuan sosial dan kemampuan intelektual siswa.Pembelajaran model tematik integratif menciptakan siswa yang aktif, kreatif, efektif, dan berpikir kritis dengan pengetahuan dan wawasan yang luas, sehingga pada akhirnya menempatkan siswa sebagai subjek dan sekaligus objek belajar, karena melibatkan siswa dalam pembelajaran (Trianto, 2010: 136).

d) Hasil pengujian hipotesis kedua adalah menunjukkan bahwa model pembelajaran terpadu memberikan pengaruh yang berbeda terhadap hasil belajar IPA jika diterapkan pada siswa yang memiliki kemampuan berpikir kritis yang berbeda pula. Model pembelajaran terpadu dan kemampuan berpikir kritis siswa terhadap 
Pengaruh Model Pembelajaran

Nurul Fazriyah

hasil belajar IPA memiliki efektifitas pada level yang berbeda. Pada siswa yang memiliki kemampuan berpikir kritis tinggi model tematik integratif lebih efektif dibandingkan model fragmented, sebaliknya pada siswa yang memiliki kemampuan berpikir krtiis rendah model tematik integrative kurang efektif dibandingkan freagmented. Hasil analisa data dengan menggunakan ANAVA dua jalur pada taraf signifikansi $\alpha=0,05$, tersebut di atas, memberikan nilai $F_{\text {hitung }}\left(F_{\text {hit }}\right)=54,04>$ dari $F_{\text {tabel }}\left(F_{t}\right)=4,07$ hal ini berarti bahwa $\mathrm{H}_{0}$ ditolak. Yang berarti bahwa terdapat pengaruh interaksi yg sangat signifikan antara model pembelajaran terpadu dengan kemampuan berpikir kritis siswa terhadap hasil belajar IPA. Interaksi tersebut dibuktikan dengan penelitian yang relevan Tunjungsari Sekaringtyas (2013:145), berdasarkan terdapat pengaruh langsung positif untuk variabel berpikir kritis terhadap hasil belajar IPA.

e) Model pembelajaran tematik integratif merangsang siswa untuk berpikir lebih tinggi karena harus menghubungkan berbagai konsep serta pengetahuan yang dipayungi dengan tema yang menarik. Kemampuan berpikir tinggi inilah yang dikatakan Costa dalam Kowiyah (2012:178) yang perlu diasah serta dikembangkan lebih lanjut dalam pembelajaran

\section{PEMBAHASAN}

Hasil pengujian hipotesis yang ketiga menunjukkan bahwa pada kelompok siswa yang memiliki KBK tinggi lebih efektif menggunakan Model Tematik Integratif dibanding Model Fragmented Pembuktian hipotesis ketiga ini sejalan dengan penelitian Muhardjito (2008:116) dalam penelitiannya menemukan pengaruh kemampuan berpikir kritis mahasiswa pada mata kuliah Fisika Dasar terhadap hasil belajar Fisika Dasar. Anak yang memiliki kemampuan berpikir kritis tinggi bila dirangsang dengan menggunakan pembelajaran tematik integrative akan lebih meningkat hasil belajarnya sesuai dengan pendapat (Kim, 1998:91).

Hasil hipotesis yang keempat menunjukkan bahwa siswa yang memiliki Kemampuan Berpikir Kritis rendah, skor hasil belajar kelompok yang diberi fragmented lebih tinggi. Adapun hasil uji Tuckey pada kelompok siswa yang mempunyai kemampuan berpikir kritis rendah diperoleh nilai $\mathrm{q}_{\text {hitung }}=4,76$ lebih besar dari $\mathrm{q}_{\text {tabel}(0,05)(4 ; 11)}=4,26$. Hal ini berarti bahwa terdapat perbedaan hasil belajar IPA kelompok siswa yang diberi pembelajaran model tematik integratif dan kelompok siswa 
yang diberi pembelajaran model fragmented untuk kelompok siswa yang mempunyai kemampuan berpikir kritis rendah. Dengan demikian dapat disimpulkan bahwa pada kelompok siswa yang mempunyai kemampuan berpikir kritis rendah, hasil belajar IPA kelompok siswa yang diberi pembelajaran model fragmentedlebih tinggi daripada hasil belajar IPA kelompok siswa yang diberi pembelajaran model tematik integratif.

Diterimanya hipotesis penelitian yang keempat sejalan dengan pendapat Jufri (2013: 58) bahwa karakterisitk anak yang memiliki kemampuan kritis hendaknya mampu membuat keputusan kritis dan kreatif, namun, siswa yang kemampuan berpikir kritisnya rendah tidak dapat membuat berbagai keputusan rumit, apalagi menghubungkan berbagai konsep serta tema yang disajikan oleh gurunya lewat pembelajaran.

Maka siswa yang kemampuan berpikir kritis rendah hasil belajarannya akan lebih rendah jika menggunakan model pembelajaran tematik integratif dibandingkan kelompok yang belajar dengan model pembelajaran fragmented. Karena mereka belum terampil menghubungkan berbagai konsep, dan tema.

\section{SIMPULAN}

Kesimpulan penelitian ini adalah (1) Model Pembelajaran Tematik Integratif memiliki pengaruh yang lebih efektif terhadap hasil belajar IPA dibandingkan Model Pembelajaran fragmented, (2) Terdapat pengaruh interaksi antara Model Pembelajaran Tematik Integratif dengan Kemampuan Berpikir Kritis terhadap hasil belajar IPA, (3) Model Pembelajaran Tematik Integratif memiliki pengaruh terhadap hasil belajar IPA pada kelompok siswa yang memiliki Kemampuan Berpikir Kritis tinggi, (4) kelompok siswa yang memiliki kemampuan berpikir kritis rendah hasil belajar IPA lebih tinggi jika menggunakan model pembelajaran fragmented.

\section{DAFTAR RUJUKAN}

Ali, Mohammad et al. 2007. Ilmu dan Aplikasi Pendidikan. Bandung: Pegagogiana Press.

Anderson, Rin. W dan David R. Krathwohl. 2001. A Taxonomy For Learning, Teaching and Assessing: A Revision of Bloom's Taxonomy of Educational Objektives. New York: Addison Wesley Longman, Inc.

Bundu, 2006. Patta. Penilaian Keteramplan Proses dan Sikap Ilmiah dalam Pembelajaran Sains SD. Jakarta: Dirjen Pendidikan Nasional. 
Pengaruh Model Pembelajaran

Nurul Fazriyah

ICELS. “Robert Gagne's Five Categories of Learning Outcomes and The Nine Events of Instruction,". ICELS Online. http://www.icels-educatorsforlearning.ca/index.php?options $=\mathrm{co}$ $\underline{\mathrm{m} \text { content } \& \text { view }=\text { article } \& \mathrm{id}=54 \& \text { ite }}$ $\underline{\text { mid }=73 \# \text { main. }}$ (Diakses 1 Januari 2014).

Kowiyah, "Kemampuan Berpikir Kritis." Jurnal Pendidikan Dasar. Nomor 5 Tahun 3, Desember 2012. Jakarta : Universitas Negeri Jakarta.

Majid, Abdul. 2013 Strategi Pembelajaran. Bandung: Remaja Rosda Karya.

Rusman. 2011. Model- Model Pembelajaran. Mengembangkan Profesionalisme Guru. Jakarta: Raja Grafindo.

Sisdiknas. "Pergeseran Paradigma Belajar Abad 21," Sisdiknas Online. http:// www.kemdikbud.go.id/kemdikbud/uj i-publik-kurikulum_20-13-2.htm (Diakses 1 Oktober 2013).

Samatowa, Usman. 2011. Pembelajaran IPA di Sekolah Dasar. Jakarta: Indeks,

Semiawan, Conny. 2007. Landasan Pembelajaran dalam Perkembangan Manusia. Jakarta : Pusat Pengembangan Kemampuan Manusia,

Siregar, Eveline dan Hartati Nara. 2010. Teori Belajar dan Pembelajaran. Bogor: Ghalia.
Sumaji. 2009 Pendidikan Sains yang Humanistis. Yogyakarta: Kanisius

Syaefudin Saud, Udin. 2009. Inovasi Pendidikan. Bandung: Alfabeta, Trilling, Bernie dan Charles Fadel. 2009. $21^{\text {st }}$ Century Skills. Learning For Life In Our Times. San Fransisco: JosseyBass. 